University of Nebraska - Lincoln DigitalCommons@University of Nebraska - Lincoln

US Army Research

U.S. Department of Defense

2006

\title{
Preclinical and clinical progress of particle- mediated DNA vaccines for infectious diseases
}

Deborah Fuller

University of Pittsburgh, School of Medicine, dfuller@pitt.edu

Peter Loudon

PowderMed, Ltd.

Connie Schmaljohn

United States Army Medical Research Institute for Infectious Diseases

Follow this and additional works at: http://digitalcommons.unl.edu/usarmyresearch

Fuller, Deborah; Loudon, Peter; and Schmaljohn, Connie, "Preclinical and clinical progress of particle-mediated DNA vaccines for infectious diseases" (2006). US Army Research. 284.

http://digitalcommons.unl.edu/usarmyresearch/284

This Article is brought to you for free and open access by the U.S. Department of Defense at DigitalCommons@University of Nebraska - Lincoln. It has been accepted for inclusion in US Army Research by an authorized administrator of DigitalCommons@University of Nebraska - Lincoln. 


\title{
Preclinical and clinical progress of particle-mediated DNA vaccines for infectious diseases
}

\author{
Deborah H. Fuller ${ }^{\mathrm{a}, *}$, Peter Loudon ${ }^{\mathrm{b}}$, Connie Schmaljohn ${ }^{\mathrm{c}}$ \\ ${ }^{a}$ Department of Molecular Genetics and Biochemistry, University of Pittsburgh, School of Medicine, 260 Kappa Drive, Pittsburgh, PA 15238, USA \\ ${ }^{\mathrm{b}}$ PowderMed, Ltd., 4 Robert Robinson Avenue, Oxford Science Park, Oxford OX4 4GA, UK \\ ${ }^{\mathrm{c}}$ United States Army Medical Research Institute for Infectious Diseases, Fort Detrick, MD, USA
}

Accepted 10 May 2006

\begin{abstract}
This review provides an overview of studies employing particle-mediated epidermal delivery (PMED) or the gene gun to administer DNA vaccines for infectious diseases in preclinical studies employing large animal models and in human clinical trials. It reviews the immunogenicity and protective efficacy of PMED DNA vaccines in nonhuman primates and swine and studies that have directly compared the effectiveness of PMED in these large animal models to existing licensed vaccines and intramuscular or intradermal delivery of DNA vaccines with a needle. Various clinical trials employing PMED have been completed and an overview of the immunogenicity, safety, and tolerability of this approach in humans is described. Finally, efforts currently in progress for commercial development of particle-mediated DNA vaccines are discussed.
\end{abstract}

(C) 2006 Elsevier Inc. All rights reserved.

Keywords: DNA vaccine; Particle-mediated epidermal delivery; Gene gun; Nonhuman primate; Swine; Human clinical trial

\section{Introduction}

DNA vaccines were introduced over 14 years ago as a novel method for vaccination $[1,2]$ and showed considerable promise in rodents through the induction of robust cytotoxic $\mathrm{T}$ cell responses and antibody and protection against a wide variety of infections [3]. However, studies employing a needle to inject DNA vaccines into the muscle or dermis proved to be disappointing in larger animals and humans, producing only sporadic, low levels of immune responses despite the use of over 1000-fold higher doses of DNA than what had proved to be effective in rodents [4]. Because early clinical trials showed less than optimal immunogenicity, development of methods that increase DNA vaccine potency has been a primary focus of research in this area in more recent years. These efforts have

\footnotetext{
* Corresponding author. Fax: +1 4129676568.

E-mail address: dfuller@pitt.edu (D.H. Fuller).
}

included improvements in vector design [5-8], the use of a viral vectored or protein vaccines to boost DNA-primed responses (i.e. prime-boost regimens) [9-11], formulation with adjuvants or cytokines [12-14], and improved DNA vaccine delivery methods [15-17]. In this review, we discuss the progress of particle-mediated epidermal delivery of DNA vaccines with an emphasis on its effectiveness in preclinical studies in large animal models (nonhuman primates and swine) and human clinical trials.

\section{Particle-mediated epidermal delivery of DNA vaccines}

Particle mediated epidermal delivery (PMED) also called the "gene gun", involves the use of a needle-free device that delivers gold particles coated with DNA plasmids encoding vaccine antigens into the epidermal layer of the skin. PMED differs from intramuscular or intradermal injection of DNA with a needle and syringe in that it results in direct delivery of the vaccine into the intracellular environment [18]. The DNA is delivered into both non- 
professional APCs (i.e. keratinocytes) and professional antigen presenting cells (i.e. Langerhans cells) of the viable epidermis $[19,20]$. Since the earliest DNA vaccine studies, direct comparisons of PMED to needle-based approaches for DNA vaccine delivery in mice [21-27] and monkeys [28-31] have shown that PMED can induce higher antibody and/or $\mathrm{CD} 8^{+} \mathrm{T}$ cell responses with substantially lower doses (100-1000-fold) of DNA. The effectiveness of this system is likely related to the use of a delivery technology that deposits DNA directly into cells $[18,20]$ as well as the immune competence of the epidermis as a delivery site $[32,33]$. These features are also believed to be responsible for the ability of this technology to induce robust levels of immune responses in both small and large animals with very small doses (i.e. $1-10 \mu \mathrm{g}$ ) of DNA.

\section{Optimization of PMED in large animal preclinical models}

The earliest large animal studies employing the PowderMed (formally PowderJect) delivery device for PMED were in nonhuman primates and required 5-7 doses to induce a significant immune response [34-36]. However, optimization of the delivery device [37], vaccine vectors [38], and immunization regimens $[26,38]$ substantially improved this technology so that later studies employing a clinical research device achieved robust and protective levels of immunity in nonhuman primates after only 1-3 doses $[29,30,39,40]$. Recent studies have shown that the delivery device employed can influence the immunogenicity of PMED in nonhuman primates. The Bio-Rad Helios device has been used in nonhuman primates and shown to require 45-60 $\mu$ g of DNA administered over 45+ sites to induce a significant response in $100 \%$ of the immunized animals $[41,42]$. This result may be due to differences in the delivery footprint of the two devices. The PowderMed device used in nonhuman primates delivers 8-fold more DNA-coated gold particles into a larger delivery site than the Bio-Rad device (DH Fuller, unpublished).

The nonhuman primate immune system is considered the best animal model for predicting the immunogenicity of a vaccine in humans. However, the skin of monkeys is significantly different from humans, being thinner and not attached to the underlying muscle. Pig skin is very similar in both structure and thickness to human skin [43], and the swine has been the model of choice for preclinical studies designed to optimize PMED delivery parameters and tolerability in the skin.

\section{PMED DNA vaccines for HIVISIV in nonhuman primates}

PMED DNA vaccines expressing HIV or SIV genes have been tested in nonhuman primates alone (Table 1) and in combination with recombinant protein or viral vectored vaccines in a prime-boost regimen (heterologous boosting) (Table 2). Heterologous boosting substantially increases the immunogenicity of PMED DNA vaccines. However, it is not clear at this time if it improves protection since partial (i.e. durable virus load reduction or delay in disease progression) to complete (i.e. prevention of infection or disease) protection has been achieved with (Table 1) and without (Table 2) boosting. Studies that have directly compared PMED alone or in combination with heterologous boosting are not consistent. In one study, boosting with a recombinant vaccinia virus substantially increased antibody responses but was less effective than PMED DNA vaccination alone in reducing viral load and delaying disease following intravenous infection with a primary isolate of SIV [35]. In a second study, vaccinia boosting was clearly superior to PMED DNA vaccination alone in protection against a pathogenic SHIV89.6P challenge with respect to reduction in virus load and protection from disease [44].

With few exceptions [45,46], PMED DNA vaccines have consistently induced at least transient viral containment and partial to complete protection against AIDS viruses in nonhuman primates (Table 1). In one study, a PMED DNA vaccine prime followed by boosting with a recombinant fowlpox virus vaccine afforded complete protection against a nonpathogenic HIV infection [47]. In another study, a PMED DNA vaccine in the absence of heterologous boosting protected 4/7 macaques from infection and/ or disease following challenge with a highly pathogenic primary SIV isolate [48]. More recently, PMED has also been effectively used for immunotherapeutic DNA vaccination in combination with antiretroviral therapy in SIV-infected macaques. In this study, a PMED DNA vaccine effectively boosted virus-specific $\mathrm{T}$ cell responses, reduced viral load during drug therapy, and then maintained containment of viremia for 6 months to 1 year (the duration of the study) even after the antiretroviral drug was removed [49].

The immune mechanisms responsible for preventing or controlling HIV are not clear. However, much evidence suggests a critical role for $\mathrm{CD}^{+}$and $\mathrm{CD} 8^{+} \mathrm{T}$ cell responses $[50,51]$. Nonhuman primate studies have shown that particle-mediated HIV/SIV DNA vaccines alone (Table 1) or in combination with heterologous boosting (Table 2) effectively induce $\mathrm{CD} 8^{+} \mathrm{T}$ cells responses. $\mathrm{CD} 4^{+} \mathrm{T}$ cell responses are also induced and where tested, the nature of this response was shown to be predominantly Th1 [47,48], a type of $\mathrm{T}$ helper response that produces IFN $\gamma$ and TNF $\alpha$ cytokines and is associated with stronger $\mathrm{CD}^{+} \mathrm{T}$ cell responses. This result is in contrast to earlier studies conducted in mice that showed PMED DNA vaccines induced predominantly a Th2 response [52-56], and demonstrates that the nature of the immune response induced by a vaccine in mice does not predict the outcome in nonhuman primates.

An effective vaccine against AIDS will need to protect against sexual transmission and may require a vaccine that induces mucosal immune responses at the site of exposure. The skin can function as an effective inductive site for both mucosal and systemic immune responses [57,58], and administration of vaccines to the skin by PMED induces immune responses in both the blood and mucosal compartments $[48,59]$. In one study, an SIV DNA vaccine 
Table 1

Particle-mediated DNA vaccines for HIV/SIV in nonhuman primates: Studies without protein or viral vector boosting

\begin{tabular}{|c|c|c|c|c|c|c|c|c|c|}
\hline \multirow[t]{2}{*}{ Pathogen } & \multirow[t]{2}{*}{ DNA vaccine } & \multirow[t]{2}{*}{ Species } & \multicolumn{5}{|c|}{ Immunogenicity } & \multirow{2}{*}{$\begin{array}{l}\text { Challenge virus, protective efficacy and } \\
\text { comments }\end{array}$} & \multirow[t]{2}{*}{ Ref. $^{b}$} \\
\hline & & & $\begin{array}{l}\text { Binding } \\
\text { antibody }\end{array}$ & $\begin{array}{l}\text { Neutralizing } \\
\text { antibody }\end{array}$ & CD8 & CD4 & Mucosal & & \\
\hline SIV & $\begin{array}{l}\text { SIV Env, virus-like } \\
\text { particles }\end{array}$ & Rhesus $^{\mathrm{a}}$ & Yes & Yes & Yes & nd & nd & $\begin{array}{l}\text { Homologous intravenous SIVmac } 251 \text {. } \\
\text { Reduction in plasma antigenemia but not cell- } \\
\text { associated virus in } 3 / 3\end{array}$ & {$[36]$} \\
\hline SIV & SIVgp120 & Rhesus & Yes & Yes & nd & nd & nd & $\begin{array}{l}\text { Induced cross-neutralizing antibody against } 2 \\
\text { primary isolates of SIV }\end{array}$ & {$[34]$} \\
\hline SIV & SIVgp 120 & Rhesus & Yes & nd & nd & nd & nd & $\begin{array}{l}\text { Increasing the rest period between doses } \\
\text { increases immunogenicity of DNA } \\
\text { immunization in macaques }\end{array}$ & {$[38]$} \\
\hline SIV & SIVgp120, SIVgp160 & Rhesus & Yes & Yes & nd & nd & nd & $\begin{array}{l}\text { Heterologous, intravenous SIV/ } \Delta B 670 \text {. Virus } \\
\text { load reduced and CD4 decline delayed in } 3 / 3\end{array}$ & {$[35]$} \\
\hline SIV & $\begin{array}{l}\text { Expression libraries } \\
\text { alone or co-delivered } \\
\text { with GM-CSF and IL-12 }\end{array}$ & Rhesus & Yes & nd & Yes & Yes & nd & $\begin{array}{l}\text { Homologous, intravenous SIVmac } 251 . \\
\text { Transient VL reduction and delayed disease } \\
\text { progression in } 2 \text { of } 3 \text { groups. Co-delivery of } \\
\text { GM-CSF and IL- } 12 \text { cytokines in the } 3 \text { rd group } \\
\text { enhanced infection and disease }\end{array}$ & [79] \\
\hline SIV & SIV gag, pol, env & Rhesus & Yes & nd & Yes & Yes (Th1) & $\begin{array}{l}\text { Yes }(\operatorname{IgG}, \\
\text { IgA, CTL) }\end{array}$ & $\begin{array}{l}\text { Heterologous, intrarectal SIV/ } \Delta \mathrm{B} 670 \text {, Virus } \\
\text { loads low to undetectable and protection } \\
\text { against disease in } 4 / 7\end{array}$ & {$[48]$} \\
\hline HIV-2 & Expression library & Babboon & Yes & Yes & Yes & Yes & nd & $\begin{array}{l}\text { Prechallenge antibody and CMI detectable but } \\
\text { low. Homologous, intravenous HIV- } 2 \\
\text { challenge. } 0 / 2 \text { protected. No evidence of virus } \\
\text { load reduction }\end{array}$ & {$[45]$} \\
\hline SIV & $\begin{array}{l}\text { SIV CTL epitopes, gag, } \\
\text { tat }\end{array}$ & Rhesus & nd & nd & Yes & Yes & nd & $\begin{array}{l}\text { Therapeutic vaccine study. Immunization of } \\
\text { SIV/ } \triangle \mathrm{B} 670 \text {-infected animals during } \\
\text { antiretroviral drug therapy (ART) prevented } \\
\text { viral rebound and disease after ART was } \\
\text { withdrawn in } 17 / 20 \text { vaccinated animals that } \\
\text { responded well to ART }\end{array}$ & [49] \\
\hline
\end{tabular}

\footnotetext{
a Rhesus macaque.

b Reference.
}

administered by PMED induced mucosal immune responses in the gut of rhesus macaques and prevented a disseminated infection at the site of exposure following intrarectal challenge with a primary isolate of SIV [48,59]. This result demonstrated the ability of PMED to induce mucosal immunity in a large animal and suggested a role for mucosal responses in protection against HIV.

To date, the collective results in nonhuman primate models for AIDS show that PMED DNA vaccines induce relevant responses and can exert significant control of AIDS viruses. Taken together, these data support PMED as a promising approach for prophylaxis or therapy of HIV.

\section{Particle-mediated DNA vaccines for emerging infectious diseases in nonhuman primates}

\subsection{Flaviviruses}

PMED studies in nonhuman primates have been conducted with DNA vaccines for the flaviviruses tick-borne encephalitis virus, (TBEV) Japanese encephalitis virus
(JEV), and Dengue virus (DENV) [40,42,60] (Table 3). Protective immunity to flavivirus infections generally correlates with a neutralizing antibody response to the envelope glycoprotein $(\mathrm{E})$. The E protein arises by cleavage of a precursor, $\mathrm{preM} / \mathrm{E}$.

DNA vaccines encoding the preM/E genes of two strains of TBEV were evaluated in cynomolgus macaques in comparison to a formalin-inactivated subunit vaccine that is commercially available in Europe [40]. Monkeys were given three vaccinations of approximately $10 \mu \mathrm{g}$ of the DNA vaccines by PMED or were given three vaccinations of the formalin inactivated vaccine at the human dose at days 0 , 30 and 70 . All of the vaccines elicited neutralizing antibodies in the monkeys, with the antibody responses persisting for at least 15 weeks after the third vaccination. Mice but not monkeys suffer uniformly fatal infections with TBEV; consequently, the protective efficacy of the PMED DNA vaccines was evaluated by passive transfer of monkey sera to mice and challenge of the mice. Complete protection of mice to challenge with either strain of TBEV was found to correlate with the neutralizing antibody titer of the monkey sera [40]. 
Table 2

Particle-mediated DNA vaccines for HIV/SIV in nonhuman primates employing a protein or viral vector boost

\begin{tabular}{|c|c|c|c|c|c|c|c|c|c|c|}
\hline \multirow[t]{2}{*}{ Pathogen } & \multirow[t]{2}{*}{ DNA vaccine Prime } & \multirow[t]{2}{*}{ Boost vaccine } & \multirow[t]{2}{*}{ Species } & \multicolumn{5}{|c|}{ Immunogenicity } & \multirow[t]{2}{*}{ Protective efficacy and comments } & \multirow[t]{2}{*}{ Ref. } \\
\hline & & & & $\begin{array}{l}\text { Binding } \\
\text { antibody }\end{array}$ & $\begin{array}{l}\text { Neutralizing } \\
\text { antibody }\end{array}$ & CD8 & $\mathrm{CD} 4$ & Mucosal & & \\
\hline \multirow[t]{2}{*}{ HIV } & HIV gag, pol, env & $\begin{array}{l}\text { Recombinant gp } 160 \\
\text { protein }\end{array}$ & Rhesus $^{\mathrm{a}}$ & Yes & Yes & nd & nd & nd & Induced cross-neutralizing antibody & [34] \\
\hline & & & & & & & & & $\begin{array}{l}\text { Heterologous nonpathogenic intravenous SHIV- } \\
\text { SF2. Transient reduction in acute VL in } 3 / 5^{\mathrm{b}}\end{array}$ & $\begin{array}{l}\text { (Unpublished } \\
\text { D Fuller) }\end{array}$ \\
\hline SIV & SIV env & Vaccinia virus & Rhesus & Yes & Yes & nd & nd & nd & $\begin{array}{l}\text { Heterologous, intravenous SIV/ } \triangle B 670,100-200- \\
\text { fold VL reduction and delayed CD4 decline } \\
\text { in } 3 / 3\end{array}$ & {$[35]$} \\
\hline SHIV & $\begin{array}{l}\text { HIV env, gag, tat, nef, } \\
\text { rev }\end{array}$ & $\begin{array}{l}\text { Recombinant Env } \\
\text { (gp160), Gag,Tat, } \\
\text { Nef, Rev protein }\end{array}$ & Cyno $^{\mathrm{b}}$ & Yes & Yes & nd & Yes & nd & $\begin{array}{l}\text { Neutralizing antibody against } \text { HIV }_{L A I} \text { and } \\
\text { SHIV-4. No evidence of protection following } \\
\text { intravenous infection with homologous SHIV-4 }\end{array}$ & [46] \\
\hline HIV & HIV env, gag & Fowlpox virus & Rhesus & Yes & nd & Yes & Yes (Th1) & nd & $\begin{array}{l}\text { Homologous, nonpathogenic, intravenous } \\
\text { HIV }_{L A I} \text { Protection from infection (no detectable } \\
\text { plasma viremia) in } 4 / 4\end{array}$ & [47] \\
\hline SHIV & HIV env, SIV gag, pol & MVA & Rhesus & Yes & Yes & Yes & nd & nd & $\begin{array}{l}\text { Homologous intrarectal SHIV } 89.6 \mathrm{P} \text {, sustained } \\
\text { VL containment and protection from CD } 4 \\
\text { decline in } 1 / 4\end{array}$ & {$[80]$} \\
\hline SIV & $\begin{array}{l}\text { Single SIV gag CTL } \\
\text { epitope }\end{array}$ & $\begin{array}{l}\text { Modified Vaccinia } \\
\text { Ankara (MVA) }\end{array}$ & Rhesus & $\mathrm{n} / \mathrm{a}$ & $\mathrm{n} / \mathrm{a}$ & Yes & nd & nd & $\begin{array}{l}\text { Homologous SIV/mac } 251 \text {, intravenous. } \\
\text { Protection from infection in } 1 / 3\end{array}$ & {$[81]$} \\
\hline SIV & $\begin{array}{l}\text { Single SIV Gag CTL } \\
\text { epitope }\end{array}$ & MVA & Rhesus & nd & nd & Yes & nd & nd & $\begin{array}{l}\text { Homologous, intrarectal SIVmac239 challenge. } \\
\text { VL reduction in } 2 / 8\end{array}$ & {$[82,83]$} \\
\hline SIV & $\begin{array}{l}\text { SIV Gag, Pol, Env, } \\
\text { Rev, Tat, Nef, vif, vpx }\end{array}$ & MVA & Rhesus & nd & $\begin{array}{l}\text { Yes (low } \\
\text { levels) }\end{array}$ & Yes & Yes & nd & $\begin{array}{l}\text { Homologous intrarectal SIVmac239. Transient } \\
\text { VL reduction in } 7 / 7\end{array}$ & [84] \\
\hline SIV & $\begin{array}{l}2 \text { SIV CTL epitopes, } \\
\text { SIV nef, tat }\end{array}$ & MVA & Rhesus & nd & nd & Yes & Yes & $\begin{array}{l}\text { Yes }(\mathrm{CD} 8, \\
\text { CD4) }\end{array}$ & $\begin{array}{l}\text { Homologous intrarectal SIVmac239, transient } \\
\text { VL reduction in } 3 / 3\end{array}$ & [85] \\
\hline SHIV & $\begin{array}{l}\text { Env, Rev, Gag, Pol, } \\
\text { Tat, Rev, Vif, Vpu/ } \\
\text { Vpx, Vpr, nef }\end{array}$ & Vaccinia virus & Pig-tailed ${ }^{c}$ & Yes & nd & Yes & nd & nd & $\begin{array}{l}\text { Homologous SHIV89.6P, intrarectal. Sustained } \\
\text { VL reduction and prevention of CD4 decline } \\
\text { in } 5 / 6\end{array}$ & [44] \\
\hline
\end{tabular}

\footnotetext{
a Rhesus macaque.

${ }^{b}$ Cynomologus macaque.

${ }^{c}$ Pig-tailed macaque.
} 
Table 3

Particle-mediated DNA vaccines for emerging infectious diseases in nonhuman primates

\begin{tabular}{|c|c|c|c|c|c|c|}
\hline \multirow[t]{2}{*}{ Pathogen } & \multirow[t]{2}{*}{ DNA vaccine } & \multirow[t]{2}{*}{ Species } & \multicolumn{2}{|c|}{ Immunogenicity } & \multirow[t]{2}{*}{ Protective efficacy and comments } & \multirow[t]{2}{*}{ Ref. } \\
\hline & & & $\begin{array}{l}\text { Binding } \\
\text { antibody }\end{array}$ & $\begin{array}{l}\text { Neutralizing } \\
\text { antibody }\end{array}$ & & \\
\hline $\begin{array}{l}\text { Russian spring summer } \\
\text { encephalitis (RSSE), } \\
\text { Central European } \\
\text { encephalitis (CEEV) }\end{array}$ & prM and $\mathrm{E}$ & Rhesus $^{\mathrm{a}}$ & Yes & Yes & $\begin{array}{l}\text { Neutralizing antibody induced by PMED was comparable } \\
\text { to levels induced by commercially licensed vaccine. Passive } \\
\text { transfer of sera from immunized macaques protected or } \\
\text { partially protected mice challenged with RSSE and CEEV }\end{array}$ & {$[40]$} \\
\hline Ebola (MARV) & GP & Cyno $^{b}$ & Yes & nd & $\begin{array}{l}\text { Subcutaneous challenge with MARV. Survival and viral } \\
\text { clearance in } 4 / 6\end{array}$ & {$[61]$} \\
\hline Japanese encephalitis & prM and $\mathrm{E}$ & Cyno & nd & Yes & $\begin{array}{l}\text { Neutralizing antibody recall following intranasal challenge } \\
\text { with Japanese encephalitis }\end{array}$ & {$[42]$} \\
\hline \multirow[t]{2}{*}{ Hepatitis E } & $\begin{array}{l}\text { Full-length ORF of } \\
\text { HEV }\end{array}$ & Cyno & Yes & nd & Intravenous challenge with heterologous HEV & {$[28]$} \\
\hline & & & & & No detectable virus in $3 / 3$ & \\
\hline Andes virus & $\begin{array}{l}\text { M gene of Andes } \\
\text { virus (ANDV) }\end{array}$ & Rhesus & Yes & Yes & $\begin{array}{l}\text { Passive transfer of sera from immunized macaques } \\
\text { protected hamsters from ANDV }\end{array}$ & {$[62]$} \\
\hline Hantaan/Andes virus & $\begin{array}{l}\text { M genes of ANDV } \\
\text { and HTNV }\end{array}$ & Rhesus & Yes & Yes & $\begin{array}{l}\text { Cross-neutralizing antibody against both HPS and HFRS } \\
\text { hantaviruses. Long-term memory B cell response that } \\
\text { exhibited rapid recall and broad neutralizing capacity to } \\
\text { subsequent boosting lyear after the initial dosing }\end{array}$ & {$[63]$} \\
\hline Dengue-2 & PrM and E & Rhesus & nd & Yes & $\begin{array}{l}\text { Intravenous challenge with Dengue- } 2 \text {. No detectable } \\
\text { viremia or viremia present only } 1 \text { day post-challenge in } 6 / 6 \\
\text { macaques that received a minimum of } 2 \text { doses }\end{array}$ & {$[60]$} \\
\hline
\end{tabular}

\footnotetext{
a Rhesus macaque.

b Cynomologus macaque.
}

Four distinct serotypes of dengue virus (DEN-1, DEN-2, DEN-3 and DEN-4) cause human disease. There is no cross-protective immunity in humans among the four serotypes. Although monkeys do not mimic human dengue infections, it is possible to measure viremia in monkeys after challenge. A DNA vaccine expressing the preM/E genes of DEN-2 delivered by PMED was shown to elicit neutralizing antibodies in all three rhesus macaques receiving four $2 \mu \mathrm{g}$ doses of DNA, in one of three monkeys receiving two $1 \mu \mathrm{g}$ vaccine doses, and in none of the three monkeys receiving only one $1 \mu \mathrm{g}$ vaccine dose [60]. Monkeys were challenged with DEN-2 virus one month after the final vaccination and monitored for viremia. In each of the two groups receiving the highest doses of vaccine, two monkeys had no viremia, and the third monkey had a single day of viremia, as compared to 4.7 days of viremia in control monkeys. Partial protection from viremia was also observed at 7 months after vaccination in additional monkeys that received two $1 \mu \mathrm{g}$ doses by PMED [60].

A JEV DNE vaccine expressing the viral preM/E genes was evaluated in two cynomolgus macaques by PMED [42]. Monkeys were vaccinated three times at intervals of 4-6 weeks with $3 \mu \mathrm{g}$ of DNA. Two weeks after vaccination, the monkeys were challenged intranasally with JEV. Both vaccinated monkeys developed neutralizing antibody responses similar to those of two monkeys given an inactivated JEV vaccine. After challenge, one of the two PMEDvaccinated monkeys developed neurological symptoms and was euthanized. The other showed a rise in neutralizing antibodies and did not develop symptoms. The number of monkeys in this study is insufficient to draw any conclusions or comparisons to other methods of delivery; however, the neutralizing antibody responses observed offer encouragement for further studies.

\subsection{Filoviruses}

A DNA vaccine expressing the surface glycoprotein (GP) of the filovirus, Marburg virus (MARV), was evaluated in 6 cynomolgus macaques in two separate PMED experiments [61]. In each study, three monkeys were vaccinated three times at 4-week intervals with $20 \mu \mathrm{g}$ DNA. All vaccinated monkeys developed antibodies to MARV as measured by ELISA. After subcutaneous challenge with MARV, all of the monkeys developed fevers, indicating that they were infected. In both experiments, two of three monkeys survived the challenge, showed no rises in liver enzymes and had no detectable viremia (Table 3). The other monkey in each study developed viremia and died, although in one experiment, death was delayed as compared to a control monkey [61]. These results suggest that the MARV GP vaccine, when delivered by PMED, is immunogenic in monkeys, and can offer potective immunity.

\subsection{Hantaviruses}

Hantaviruses are rodent-borne viruses that can cause hemorrhagic fever with renal syndrome (HFRS) or 
hantavirus pulmonary syndrome (HPS). DNA vaccines expressing the two envelope glycoproteins, $G_{N}$ and $G_{C}$ of the HFRS-causing hantavirus, Hantaan virus (HTNV), or of the HPS-causing hantavirus, Andes virus (ANDV), were evaluated in rhesus macaques. Two monkeys per group received $\sim 6 \mu \mathrm{g}$ of each of the HTNV or ANDV DNA vaccines by PMED at weeks 0,3 , and 6 and at week 9 or 12 [62]. Neutralizing antibodies were detected after the first vaccination and rose to very high levels after the final vaccination. Monkeys are not a lethal challenge model for hantaviruses; however, hamsters will succumb to Andes virus challenge and they can be infected by HTNV, although they do not become ill. Consequently, to evaluate the protective efficacy of the PMED-delivered HTNV and ANDV DNA vaccines, sera from the vaccinated monkeys were passively transferred to hamsters and the hamsters were challenged with ANDV or HTNV. All hamsters that received transferred sera from ANDV DNA-vaccinated monkeys 4 or 5 days before challenge were protected from the ANDV challenge (Table 3). Six of 8 hamsters given sera from HTNV DNA-vaccinated monkeys showed no evidence of infection after HTNV challenge, suggesting sterile immunity [62]. In a follow-up study, monkeys were boosted 1-2 years after their initial vaccination series [63]. Very strong anamnestic responses were observed in monkeys given a single boost with either the ANDV or HTNV DNA vaccines, with the monkeys developing neutralizing antibody titers higher than those achieved following the initial vaccination series. In this same study, two monkeys were vaccinated by PMED four times at 3-week intervals with a DNA vaccine expressing the $G_{N}$ and $G_{C}$ genes of both ANDV and HTNV [63]. These monkeys developed neutralizing antibodies to both viruses, albeit at lower levels than the monkeys that received the individual HTNV or ANDV DNA vaccines. The antibody responses could be boosted dramatically by a single PMED vaccination at week 85 . These studies show that PMED vaccination can elicit long-lived neutralizing antibody responses in nonhuman primates that can be readily boosted with additional vaccinations.

\subsection{Hepatitis E virus}

Hepatitis E is a non-enveloped positive strand RNA virus, which has yet to be propagated in cell culture. Antibody responses to the capsid protein have been shown to correlate with protective immunity. Three cynomolgus macaques received 4 PMED vaccinations at 4-week intervals of approximately $25 \mu \mathrm{g} /$ dose of a DNA vaccine expressing the capsid protein of HEV [28]. All three vaccinated monkeys developed antibody responses and were protected from challenge with HEV (Table 3). HEV RNA was not detected in the stool or serum samples of any of the PMED-vaccinated and HEV-challenged monkeys. In contrast, control monkeys that received a mock DNA construct or that received the vaccine by intradermal injection did not develop antibodies to HEV and were not protected from challenge [28]. These data show a clear correlation between antibody responses and protection and point toward potential development of a PMED-delivered DNA vaccine for HEV.

\section{Particle-mediated DNA vaccines as an alternative for existing vaccines: studies in nonhuman primates and swine}

Several studies investigated particle-mediated DNA vaccines as an alternative approach to existing vaccines and directly compared PMED to licensed vaccines in either nonhuman primates or swine (Table 4). In swine, 3 doses of $0.5-1.5 \mu \mathrm{g}$ of a hepatitis B DNA vaccine administered by PMED induced protective levels of antibody that were comparable to levels induced with 3 doses of a licensed recombinant protein vaccine [64]. Similarly, 2 doses of a rabies DNA vaccine administered by PMED induced comparable antibody and protection against lethal infection with rabies virus as a human diploid cell vaccine (HDCV) [29]. A single dose of this rabies DNA vaccine also afforded post-exposure protection [65] and induced memory B cell responses that afforded protection 1 year post-immunization [39]. These results demonstrate that particle-mediated DNA vaccines can induce durable immunity and be effectively used for post-exposure prophylaxis.

Immunization of swine with an influenza DNA vaccine [66] and monkeys with either a measles DNA vaccine [31] or a smallpox DNA vaccine [67] by PMED induced antibody responses that were, on average, 2-10-fold lower than the respective licensed killed whole virus vaccine for influenza, the Moraten live attenuated vaccine for measles, and the DryVax vaccine for smallpox (Table 4). Nevertheless, these DNA vaccines still provided significant protection from infection. In the influenza [66] and measles [31] studies, protection was similar to that provided by the licensed vaccines, demonstrating that although PMED induced lower immunogenicity than the existing vaccines, the levels were still sufficient to afford full protection.

In nonhuman primates, PMED has been directly compared to parenteral delivery of DNA vaccines with a needle. Where tested, PMED induced comparable $\mathrm{CD}^{+} \mathrm{T}$ cell responses [31] and superior antibody [29-31] with 1001000-fold less DNA when compared to injection of naked DNA into the skin or muscle with a needle. Similarly, in swine, administration of a porcine RSV DNA vaccine by PMED induced significantly higher antibody responses than a combined approach employing both intramuscular and intradermal inoculation of naked DNA with a needle [68]. PMED has also been shown to afford superior protection against viral infections when compared to intramuscular or intradermal DNA delivery [29,31].

\section{Human clinical trials}

PMED has been tested in human clinical trials and is, to date, the only DNA vaccine delivery method that has consistently induced significant humoral and cellular immune 
Table 4

Particle-mediated DNA vaccines as an alternative to existing vaccine strategies in preclinical studies in nonhuman primates and swine

\begin{tabular}{|c|c|c|c|c|c|c|c|c|c|}
\hline \multirow[t]{2}{*}{ Pathogen } & \multirow[t]{2}{*}{ DNA vaccine } & \multirow[t]{2}{*}{ Species } & \multicolumn{4}{|c|}{ Immunogenicity } & \multirow[t]{2}{*}{ Protective efficacy and comments } & \multirow[t]{2}{*}{ Comparison to existing vaccine } & \multirow[t]{2}{*}{ Ref. } \\
\hline & & & $\begin{array}{l}\text { Binding } \\
\text { antibody }\end{array}$ & $\begin{array}{l}\text { Neutralizing } \\
\text { antibody }\end{array}$ & CD8 & $\overline{\mathrm{CD} 4}$ & & & \\
\hline Hepatitis B & $\mathrm{sAg}$ & Rhesus $^{\mathrm{a}}$ & Yes & $\mathrm{n} / \mathrm{a}$ & nd & nd & $\begin{array}{l}\text { Protective levels of antibody induced in } 8 / 8 \text { after 1-3 } \\
\text { doses of } 4 \mu \mathrm{g} \text { DNA }\end{array}$ & nd & {$[30]$} \\
\hline Hepatitis B & sAg & Swine & Yes & $\mathrm{n} / \mathrm{a}$ & nd & nd & $\begin{array}{l}\text { Protective levels of antibody induced in } 10 / 10 \text { after } 3 \\
\text { doses of } 0.5 \text { or } 1.5 \mu \mathrm{g} \text { of DNA }\end{array}$ & $\begin{array}{l}\text { Induced comparable levels of antibody } \\
\text { when compared to immunization with a } \\
\text { commercially available hepatitis B } \\
\text { recombinant protein vaccine }\end{array}$ & {$[38]$} \\
\hline Measles & $\begin{array}{l}\text { MV H and F } \\
\text { glycoprotein }\end{array}$ & Rhesus & Yes & Yes & Yes & nd & $\begin{array}{l}2 \text { doses of } 8 \text { or } 16 \mu \mathrm{g} \text { DNA induced protective levels of } \\
\text { antibody and protected against intratracheal challenge } \\
\text { with MV in } 6 / 6(100 \%)\end{array}$ & $\begin{array}{l}2-5 \text {-fold lower antibody response than the } \\
\text { Moraten live attenuated vaccine but } \\
\text { comparable protection }\end{array}$ & {$[31]$} \\
\hline \multirow[t]{3}{*}{ Rabies } & \multirow[t]{3}{*}{ Glycoprotein (G) } & \multirow[t]{3}{*}{ Cyno $^{\mathrm{b}}$} & \multirow[t]{3}{*}{ nd } & \multirow[t]{3}{*}{ Yes } & \multirow[t]{3}{*}{ nd } & \multirow[t]{3}{*}{ nd } & $\begin{array}{l}2 \text { doses of } 10 \mu \mathrm{g} \text { of DNA induced protective levels of } \\
\text { antibody and protected against a lethal challenge with } \\
\text { wild-type rabies virus in } 4 / 4(100 \%)\end{array}$ & $\begin{array}{l}\text { Comparable antibody responses and } \\
\text { protection to a human diploid cell vaccine } \\
\text { (HDCV) }\end{array}$ & [29] \\
\hline & & & & & & & $\begin{array}{l}\text { A single dose of } 8-60 \mu \mathrm{g} \text { of DNA protected } 3 / 5(60 \%) \\
\text { macaques against lethal challenge with wild-type rabies } \\
\text { virus } 1 \text { year post-immunization }\end{array}$ & ND & {$[39]$} \\
\hline & & & & & & & $\begin{array}{l}\text { Post-exposure vaccination with } 60 \mu \mathrm{g} \text { DNA in } \\
\text { combination human rabies immunoglobulin protected } \\
2 / 4(50 \%)\end{array}$ & $\begin{array}{l}\text { Post-exposure vaccination with } \\
\text { HDCV + immunoglobulin protected } 3 / 4 \\
(75 \%)\end{array}$ & {$[65]$} \\
\hline Influenza & $\begin{array}{l}\mathrm{HA} \text { of an } \mathrm{H} 1 \mathrm{~N} 1 \\
\text { influenza virus }\end{array}$ & Swine & Yes & Yes & nd & nd & $\begin{array}{l}2 \text { doses of } 9 \mu \mathrm{g} \text { DNA reduced viral shedding and } \\
\text { accelerated clearance in } 8 / 8 \text { following intranasal } \\
\text { challenge with homologous virus }\end{array}$ & $\begin{array}{l}\text { Induced about a } 2 \text {-fold lower antibody than } \\
\text { inactivated whole virus vaccine but similar } \\
\text { protection }\end{array}$ & {$[66]$} \\
\hline Smallpox & A27L, A33R, L1R, B5R & Rhesus & Yes & Yes & nd & nd & $\begin{array}{l}\text { Induced cross-neutralizing antibody against VACV and } \\
\text { MOPV } \\
\text { Survival and reduced disease severity in } 3 / 3 \text { macaques }\end{array}$ & $\begin{array}{l}\text { Induced higher binding antibody and } \\
\text { comparable neutralizing antibody but less } \\
\text { protection when compared to the } \\
\text { commercial smallpox vaccine (Dryvax) }\end{array}$ & {$[67,86]$} \\
\hline RSV & $\begin{array}{l}\text { Porcine RRSV } \\
\text { nucleoprotein }\end{array}$ & Swine & Yes & Yes & nd & nd & $\begin{array}{l}\text { PMED of } 32 \mu \mathrm{g} \text { of DNA into the skin of the ear was } \\
\text { superior to delivery into oral tissues for induction of } \\
\text { antibody } \\
\text { Vaccinated pigs developed a rapid recall antibody } \\
\text { response following RRSV infection }\end{array}$ & nd & {$[68,87]$} \\
\hline RSV & $\begin{array}{l}\text { Porcine RRSV } \\
\text { nucleoprotein (N) co- } \\
\text { delivered with IL-4 or } \\
\text { IL-2 }\end{array}$ & Swine & Yes & Yes & nd & Yes & $\begin{array}{l}3 \text { doses of } 60 \mu \mathrm{g} \text { DNA reduced viral shedding and } \\
\text { accelerated viral clearance in } 12 / 12 \text { following intranasal } \\
\text { challenge with a field isolate. IL- } 2 \text { enhanced T cell } \\
\text { proliferation but not protection }\end{array}$ & nd & [88] \\
\hline $\begin{array}{l}\text { Foot and } \\
\text { mouth } \\
\text { disease }\end{array}$ & $\begin{array}{l}\text { FMD genome } \\
\text { producing } \\
\text { nonpathogenic virus } \\
\text { particles }\end{array}$ & Swine & Yes & Yes & nd & nd & $\begin{array}{l}2 \text { doses of } 3 \mu \mathrm{g} \text { DNA afforded partial protection from } \\
\text { highly virulent FMD challenge in } 5 / 5\end{array}$ & nd & [89] \\
\hline
\end{tabular}

\footnotetext{
a Rhesus macaque.

${ }^{\mathrm{b}}$ Cynomologus macaque.
} 
responses in all or most vaccine recipients without adjuvants or heterologous boosting with protein or viral vectors (Table 5).

\subsection{Dosing}

The optimum DNA dosing regimen for PMED in humans was determined in clinical trials employing a hepatitis B DNA vaccine expressing the surface antigen $(\mathrm{sAg})$ of $\mathrm{HBV}$. These studies showed that a minimum of $1.0 \mu \mathrm{g}$ and 2 delivery sites was required to induce a detectable response in most subjects but higher responses and a better responder rate could be achieved by increasing the dose to 4.0 $\mu$ g DNA administered into 4 delivery sites [69,70]. A subsequent HBsAg DNA vaccine study in pre-immune subjects showed that increasing the DNA dose up to $8.0 \mu \mathrm{g}$ (4 delivery sites) provided no additional benefit, indicating that a $4.0 \mu \mathrm{g}$ DNA dose was sufficient for PMED in humans.

\subsection{Humoral responses}

A PMED hepatitis B DNA vaccine trial was the first to demonstrate that DNA immunization could be used to effectively induce humoral responses in humans [69]. Immunization with 3 doses of $1-4 \mu \mathrm{g}$ of DNA induced robust antibody in $100 \%$ of the immunized subjects at levels that exceeded the minimum required for protective immunity $(10 \mathrm{mIU} / \mathrm{ml})$. Clinical trials in pre-immune subjects also showed that a single DNA vaccine dose was sufficient to boost pre-existing hepatitis $\mathrm{B}$ and influenza-specific antibody responses [71,72]. In both of these studies, administration of a single dose of DNA by PMED increased antibody responses at least 4-10-fold in the majority of subjects. In the hepatitis B trial [72], a prototype commercial device induced similar responses as a clinical research device that had been used in earlier trials, supporting further development of this device for future commercial purposes. In the influenza trial [71], dose escalation showed that immunization with 2.0 or $4.0 \mu \mathrm{g}$ of DNA induced a higher responder rate than immunization with $1.0 \mu \mathrm{g}$, an outcome that was consistent with an earlier clinical trial employing a hepatitis B DNA vaccine [69]. Importantly, the influenza study [71] showed that a single immunization with just 2 or $4 \mu \mathrm{g}$ of DNA increased the number of subjects with seroprotective levels of antibody against influenza from 5/24 (21\%) to 22/ $23(96 \%)$, an outcome that suggests considerable promise for development of this technology as an alternative strategy for immunization against influenza.

Studies in mice showed that DNA immunization could overcome non-responsiveness to vaccination with protein vaccines [64]. A clinical trial in subjects non-responsive to commercial hepatitis B protein vaccines was therefore conducted to determine if particle-mediated DNA vaccines could be similarly used to overcome vaccine non-responsiveness in humans [73]. Interestingly, a total of 9/12 subjects that had previously failed to respond to 3-9 doses of the commercial vaccine seroconverted and developed protective levels of antibody after 1-3 DNA vaccine doses, suggesting that PMED may be an attractive alternative approach for prophylactic vaccination against hepatitis B.

\subsection{Cell-mediated immune responses}

The ability of particle-mediated DNA vaccines to induce cell-mediated immune responses in humans has been evaluated in 3 clinical trials. In the first trial, a hepatitis B DNA vaccine induced significant $\mathrm{CD} 8^{+}$and $\mathrm{CD} 4^{+}$ $\mathrm{T}$ cell responses in $100 \%(12 / 12)$ of the subjects [69]. $\mathrm{CD} 8^{+}$ $\mathrm{T}$ cell responses were MHC class I-restricted and demonstrated both cytolytic and IFN $\gamma$ effector functions. CD4 ${ }^{+}$ $\mathrm{T}$ cell responses were shown to be predominantly Th1 in nature, an outcome that is consistent with HIV/SIV DNA vaccine studies employing PMED in nonhuman primates and argues against the hypothesis propagated through mouse studies [52-56] that PMED induces a biased Th2 response.

In a second trial, a single dose of the hepatitis B DNA vaccine boosted cell-mediated immune responses in individuals that were previously primed by vaccination with a commercial hepatitis B protein vaccine [72]. A single DNA immunization induced de novo $\mathrm{CD} 8^{+} \mathrm{T}$ cell responses in several subjects and boosted $\mathrm{CD}^{+}{ }^{+} \mathrm{T}$ cell responses in the majority $(70 \%)$, an outcome that was expected because the individuals were primed by previous vaccination with the hepatitis $\mathrm{B}$ protein vaccine for $\mathrm{CD}^{+}$but not $\mathrm{CD} 8^{+} \mathrm{T}$ cell responses.

Particle-mediated DNA immunization has also been tested in humans for the ability to induce $\mathrm{T}$ cell responses in combination with heterologous boosting with a recombinant modified vaccinia Ankara vaccine (MVA) [74]. In this trial, subjects were primed with a malaria DNA vaccine encoding the Plasmodium falciparum TRAP gene and CTL epitopes by intramuscular injection of $1000 \mu \mathrm{g}$ of DNA or by PMED of $4 \mu \mathrm{g}$ DNA and then boosted with doses of MVA. A direct comparison of groups receiving identical immunization regimens (i.e. 2 DNA priming doses followed by 2 MVA boosting doses) showed a tendency toward higher IFN $\gamma$ T cell responses in the group primed by particle-mediated delivery of DNA when compared to the group primed by intramuscular DNA injection $(P=0.10)$.

The ability of PMED to effectively induce $\mathrm{CD} 8^{+}$and $\mathrm{CD}^{+} \mathrm{T}$ cell responses in humans suggests this technology will be useful for developing of novel vaccines or therapies against cancers and chronic infectious diseases such as AIDS and hepatitis B in which inducing or boosting specific $\mathrm{T}$ cell responses is a goal.

\subsection{Safety and tolerability}

Clinical trials employing PMED have uniformly demonstrated that the technology is safe and well-tolerated in humans (Table 5). PMED results in a painless 
Table 5

Particle-mediated DNA vaccines in human clinical trials

\begin{tabular}{|c|c|c|c|c|c|c|c|c|}
\hline \multirow[t]{2}{*}{ Pathogen/clinical phase } & \multirow{2}{*}{$\begin{array}{l}\text { DNA } \\
\text { vaccine }\end{array}$} & \multirow[t]{2}{*}{ Dose and regimen } & \multicolumn{3}{|c|}{ Immunogenicity and responder rate } & \multirow[t]{2}{*}{ Safety and tolerability } & \multirow[t]{2}{*}{ Comments } & \multirow[t]{2}{*}{ Ref. } \\
\hline & & & Antibody & CD8 & $\mathrm{CD} 4$ & & & \\
\hline \multicolumn{9}{|l|}{ Hepatitis $B$} \\
\hline $\begin{array}{l}\text { Phase I ascending pressure } \\
\text { study in nai"ve }(N=7)\end{array}$ & sAg & $0.25 \mu \mathrm{g}$ & Yes $(1 / 7)$ & nd & nd & $\begin{array}{l}\text { Safe and well-tolerated at all } \\
\text { pressures }\end{array}$ & $\begin{array}{l}\text { Protective levels of antibody } \\
(>10 \mathrm{mIU} / \mathrm{ml}) \text { in } 1 / 7\end{array}$ & [70] \\
\hline \multicolumn{9}{|l|}{ Hepatitis $B$} \\
\hline $\begin{array}{l}\text { Phase I ascending dose } \\
\text { study in nar"ve }(N=12)\end{array}$ & $\mathrm{sAg}$ & $\begin{array}{l}1.0 \mu \mathrm{g}(N=4) \\
2.0 \mu \mathrm{g}(N=4) \\
4.0 \mu \mathrm{g}(N=4) \\
3 \text { doses at weeks } 0,8 \\
16\end{array}$ & Yes $(12 / 12)$ & $\begin{array}{l}\text { Yes }(8 / 8) \text { Epitope-specific } \\
\text { CD } 8 \text { were measured in } \\
\text { only } 8 \text { of the } 12 \text { volunteers } \\
\text { that were positive for the } \\
\text { HLA-A2 MHC class I } \\
\text { allele }\end{array}$ & $\begin{array}{l}\text { Yes }(12 / 12) \\
\text { (Th1) }\end{array}$ & $\begin{array}{l}\text { Transient skin reactions at } \\
\text { delivery site include mild } \\
\text { erythema, flaking, and } \\
\text { discoloration. Slight edema } \\
\text { and itch. No discomfort }\end{array}$ & $\begin{array}{l}\text { Protective levels of antibody } \\
(>10 \mathrm{mIU} / \mathrm{ml}) \mathrm{in} 12 / 12 \\
\text { Highest dose }(4.0 \mu \mathrm{g}) \\
\text { produced highest and most } \\
\text { rapid antibody and CMI } \\
\text { responses }\end{array}$ & [69] \\
\hline \multicolumn{9}{|l|}{ Hepatitis $B$} \\
\hline $\begin{array}{l}\text { Phase I in non-responders } \\
\text { to licensed protein } \\
\text { vaccine }(N=16)\end{array}$ & $\mathrm{sAg}$ & $\begin{array}{l}4.0 \mu \mathrm{g} \\
3 \text { doses at weeks } 0,8 \\
16\end{array}$ & Yes $(12 / 16)$ & nd & nd & $\begin{array}{l}\text { Subjects report vaccination is } \\
\text { painless with mild tingling } \\
\text { minutes post-delivery }\end{array}$ & $\begin{array}{l}\text { Protective levels of antibody } \\
(>10 \mathrm{mIU} / \mathrm{ml}) \text { in subjects that } \\
\text { had previously failed to } \\
\text { respond to 3-9 } \\
\text { immunizations with licensed } \\
\text { protein vaccine }\end{array}$ & {$[73]$} \\
\hline \multicolumn{9}{|l|}{ Hepatitis B } \\
\hline $\begin{array}{l}\text { Phase I in pre-immune with } \\
\text { commercial device } \\
(N=30)\end{array}$ & $\mathrm{sAg}$ & $\begin{array}{l}4.0-8.0 \mu \mathrm{g} \text { single dose } \\
\text { with clinical research } \\
\text { (XR1) or commercial } \\
\text { (ND5.5) device }\end{array}$ & $\begin{array}{l}\text { Yes }(21 / 30) \\
>10 \text {-fold increase } \\
\text { in antibody }\end{array}$ & Yes (low) & $\begin{array}{l}\text { Yes }(21 / 30) \\
\text { (balanced } \\
\text { Th1/Th2) }\end{array}$ & $\begin{array}{l}\text { Both devices safe and well- } \\
\text { tolerated } \\
\text { Transient, mild skin } \\
\text { reactions similar in both } \\
\text { devices. Mild discoloration } \\
\text { persisted in some target sites } \\
\text { for }>6 \text { months }\end{array}$ & $\begin{array}{l}\text { No difference in magnitude } \\
\text { of antibody, CMI response } \\
\text { or number of responders } \\
\text { between research and } \\
\text { commercial device }\end{array}$ & {$[72]$} \\
\hline \multicolumn{9}{|l|}{ Malaria } \\
\hline $\begin{array}{l}\text { Phase I DNA prime-MVA } \\
\text { boost in naı"ve }(N=10)\end{array}$ & $\begin{array}{l}\text { TRAP and } \\
\text { epitopes }\end{array}$ & $\begin{array}{l}2-3 \text { doses of DNA } \\
\text { alone and with } 2 \\
\text { booster doses of } \\
\text { MVA }\end{array}$ & Not shown & $\begin{array}{l}\text { Yes (responder rate not } \\
\text { shown) }\end{array}$ & $\begin{array}{l}\text { Yes } \\
\text { (responder } \\
\text { rate not } \\
\text { shown) }\end{array}$ & $\begin{array}{l}\text { No antinuclear antibody } \\
\text { responses detected }\end{array}$ & $\begin{array}{l}\text { Particle-mediate DNA prime } \\
\text { and MVA boost significantly } \\
\text { delayed the development of } \\
\text { parasitemia }\end{array}$ & {$[74]$} \\
\hline \multicolumn{9}{|l|}{ Influenza } \\
\hline $\begin{array}{l}\text { Phase I in pre-immune } \\
\qquad(N=36)\end{array}$ & HA & $\begin{array}{l}1.0 \mu \mathrm{g}(N=12) \\
2.0 \mu \mathrm{g}(N=12) \\
4.0 \mu \mathrm{g}(N=12) \text { Single } \\
\text { dose }\end{array}$ & $\begin{array}{l}\text { Yes }(19 / 35) \\
>4 \text {-fold increase in } \\
\text { antibody }\end{array}$ & nd & nd & $\begin{array}{l}\text { Skin reactions followed for } \\
150 \text { days. Reactions were } \\
\text { mild and resolved after 14-28 } \\
\text { days except mild } \\
\text { discoloration persisted in a } \\
\text { few target sites for } 180 \text { days }\end{array}$ & $\begin{array}{l}\text { Higher antibody and } \\
\text { responder rate at higher } \\
\text { DNA doses. } 2-4 \mu \mathrm{g} \text { doses } \\
\text { increased the number of } \\
\text { subjects with seroprotective } \\
\text { levels of antibody from } 5 / 24 \\
(21 \%) \text { to } 22 / 23(96 \%)\end{array}$ & {$[71]$} \\
\hline
\end{tabular}


delivery of the DNA-coated gold particles into the skin. Immediately after delivery, a transient, mild skin reaction occurs that likely facilitates antigen uptake and processing by antigen presenting cells (APC) through the production of local cytokines that recruit APC to the delivery site [33]. Reactions include mild redness, discoloration, flaking, edema, rash, and/or itch. Consistent with preclinical studies in swine, these reactions resolve within 14-28 days post-delivery, although a faint discoloration can persist in some target sites for over 6 months postdelivery $[71,72]$.

\section{Future prospects for PMED}

The PMED device now being used in clinical trials is the ND10, a single use, disposable design that is appropriate for commercialization and large scale manufacture. It features an internal helium cylinder and a cassette that holds $2 \mu \mathrm{g}$ DNA coated on $1 \mathrm{mg}$ gold particles. Depression of the actuation button leads to release of the helium which bursts the cassette membranes and delivers the gold particles into the epidermis. The performance of the ND10 has been shown to be equivalent to that of previous device models in preclinical studies.

PMED DNA vaccination using the ND10 has several important advantages for vaccine delivery. Administration is needle-free thus avoiding any issues of needle stick injury or disposal of sharps, and allowing vaccination of needlephobic subjects. For some applications self administration may also be feasible. Once precipitated onto gold particles the plasmid DNA is highly stable, allowing storage at room temperature and deployment without a cold chain. Because PMED uses only microgram quantities of DNA per administration, the DNA manufacture is easy to scale up and provision of product is rapid, giving the PMED technology a competitive edge for responding to threats that demand a quick response. Hence PMED vaccines for annual and pandemic influenza are especially attractive and, supported by promising data from a phase I clinical trial of a PMED DNA influenza vaccine [71], development of representative annual and avian influenza vaccines is now underway. PMED can also elicit protective responses to multiple antigens expressed from mixtures of plasmid co-delivered in one actuation [75]. The development of potent multicomponent combination vaccines, capable of self administration and room temperature storage, may be especially useful for biodefense and a number of such vaccines are now being studied.

In addition to these prophylactic targets, the ability of PMED DNA vaccines to elicit potent cell mediated responses has led to interest in the use of the technology for therapeutic vaccination. Clinical trials are now underway for therapeutic PMED DNA vaccines for HBV, HIV, Cancer, and HSV. Future development of these and other therapeutic products is likely to focus on enhancement of potency by inclusion of genetic adjuvants and novel dosing regimens.

\section{Summary}

Early clinical studies employing parenteral needle delivery of DNA vaccines proved to be disappointing and led to the general opinion that without heterologous boosting, DNA vaccines would not be effective in the clinic. In contrast, this review shows that DNA vaccines administered by PMED, even in the absence of heterologous boosting or adjuvants, have translated well from the mouse and bench to preclinical large animal species, including nonhuman primates and pigs, and to human clinical trials. New improvements in the PMED technology [72], vector design $[25,76,77]$, including co-formulation of PMED DNA vaccines with adjuvants [78], are in progress to further enhance the potency of particle-mediated DNA vaccines. These efforts are expected to accelerate the commercialization of PMED as an effective approach for vaccination against infectious diseases.

\section{References}

[1] D.C. Tang, M. DeVit, S.A. Johnston, Nature 356 (1992) 152-154.

[2] J.B. Ulmer, J.J. Donnelly, S.E. Parker, G.H. Rhodes, P.L. Felgner, V.J. Dwarki, S.H. Gromkowski, R.R. Deck, C.M. DeWitt, A. Friedman, et al., Science 259 (1993) 1745-1749.

[3] J.J. Donnelly, J.B. Ulmer, M.A. Liu, Life Sci. 60 (1997) 163-172.

[4] M.A. Liu, J.B. Ulmer, Adv. Genet. 55 (2005) 25-40.

[5] D.H. Barouch, J. Pathol. 208 (2006) 283-289.

[6] S.A. Calarota, D.B. Weiner, Expert Rev. Vaccines 3 (2004) S135-S149.

[7] H.S. Garmory, K.A. Brown, R.W. Titball, Genet. Vaccines Ther. 1 (2003) 2.

[8] S. Manoj, L.A. Babiuk, S. van Drunen Littel-van den Hurk, Crit. Rev. Clin. Lab. Sci. 41 (2004) 1-39.

[9] N.A. Doria-Rose, N.L. Haigwood, Methods 31 (2003) 207-216.

[10] A.C. Moore, A.V. Hill, Immunol. Rev. 199 (2004) 126-143.

[11] D.L. Woodland, Trends Immunol. 25 (2004) 98-104.

[12] D.H. Barouch, N.L. Letvin, R.A. Seder, Immunol. Rev. 202 (2004) 266-274.

[13] S.A. Calarota, D.B. Weiner, Immunol. Rev. 199 (2004) 84-99.

[14] J.Y. Scheerlinck, Vaccine 19 (2001) 2647-2656.

[15] Z. Cui, R.J. Mumper, Crit. Rev. Ther. Drug Carrier Syst. 20 (2003) $103-137$.

[16] D.T. O’Hagan, R. Rappuoli, Pharm. Res. 21 (2004) 1519-1530.

[17] C.J. Pachuk, D.E. McCallus, D.B. Weiner, C. Satishchandran, Curr. Opin. Mol. Ther. 2 (2000) 188-198.

[18] N.S. Yang, J. Burkholder, B. Roberts, B. Martinell, D. McCabe, Proc. Natl. Acad. Sci. USA 87 (1990) 9568-9572.

[19] C. Condon, S.C. Watkins, C.M. Celluzzi, K. Thompson, L.D. Falo Jr., Nat. Med. 2 (1996) 1122-1128.

[20] M.D. Eisenbraun, D.H. Fuller, J.R. Haynes, DNA Cell Biol. 12 (1993) 791-797.

[21] A.M. Bennett, R.J. Phillpotts, S.D. Perkins, S.C. Jacobs, E.D. Williamson, Vaccine 18 (1999) 588-596.

[22] E.F. Fynan, R.G. Webster, D.H. Fuller, J.R. Haynes, J.C. Santoro, H.L. Robinson, Proc. Natl. Acad. Sci. USA 90 (1993) 11478-11482.

[23] H.S. Garmory, D. Freeman, K.A. Brown, R.W. Titball, Vaccine 22 (2004) 947-957.

[24] J.W. Hooper, K.I. Kamrud, F. Elgh, D. Custer, C.S. Schmaljohn, Virology 255 (1999) 269-278.

[25] J.W. Kim, C.F. Hung, J. Juang, L. He, T.W. Kim, D.K. Armstrong, S.I. Pai, P.J. Chen, C.T. Lin, D.A. Boyd, T.C. Wu, Gene Ther. 11 (2004) 1011-1018.

[26] W.W. Leitner, M.C. Seguin, W.R. Ballou, J.P. Seitz, A.M. Schultz, M.J. Sheehy, J.A. Lyon, J. Immunol. 159 (1997) 6112-6119. 
[27] C. Trimble, C.T. Lin, C.F. Hung, S. Pai, J. Juang, L. He, M. Gillison, D. Pardoll, L. Wu, T.C. Wu, Vaccine 21 (2003) 4036-4042.

[28] S. Kamili, J. Spelbring, D. Carson, K. Krawczynski, J. Infect. Dis. 189 (2004) 258-264.

[29] D.L. Lodmell, N.B. Ray, M.J. Parnell, L.C. Ewalt, C.A. Hanlon, J.H. Shaddock, D.S. Sanderlin, C.E. Rupprecht, Nat. Med. 4 (1998) 949952.

[30] M.J. McCluskie, C.L. Brazolot Millan, R.A. Gramzinski, H.L. Robinson, J.C. Santoro, J.T. Fuller, G. Widera, J.R. Haynes, R.H. Purcell, H.L. Davis, Mol. Med. 5 (1999) 287-300.

[31] F.P. Polack, S.H. Lee, S. Permar, E. Manyara, H.G. Nousari, Y. Jeng, F. Mustafa, A. Valsamakis, R.J. Adams, H.L. Robinson, D.E. Griffin, Nat. Med. 6 (2000) 776-781.

[32] L.D. Falo Jr., Proc. Assoc. Am. Physicians 111 (1999) 211-219.

[33] T. Tuting, W.J. Storkus, L.D. Falo Jr., J. Invest. Dermatol. 111 (1998) 183-188.

[34] D.H. Fuller, M. Murphey-Corb, J. Clements, S. Barnett, J.R. Haynes, J. Med. Primatol. 25 (1996) 236-241.

[35] D.H. Fuller, L. Simpson, K.S. Cole, J.E. Clements, D.L. Panicali, R.C. Montelaro, M. Murphey-Corb, J.R. Haynes, Immunol. Cell. Biol. 75 (1997) 389-396.

[36] S. Lu, J. Arthos, D.C. Montefiori, Y. Yasutomi, K. Manson, F. Mustafa, E. Johnson, J.C. Santoro, J. Wissink, J.I. Mullins, J.R. Haynes, N.L. Letvin, M. Wyand, H.L. Robinson, J. Virol. 70 (1996) 3978-3991.

[37] T.M. Pertmer, M.D. Eisenbraun, D. McCabe, S.K. Prayaga, D.H. Fuller, J.R. Haynes, Vaccine 13 (1995) 1427-1430.

[38] D.H. Fuller, M. Murphey-Corb, S. Barnett, K. Steimer, J.R. Haynes, Vaccine 15 (1997) 924-926.

[39] D.L. Lodmell, M.J. Parnell, J.R. Bailey, L.C. Ewalt, C.A. Hanlon, Vaccine 20 (2001) 838-844.

[40] C. Schmaljohn, D. Custer, L. VanderZanden, K. Spik, C. Rossi, M. Bray, Virology 263 (1999) 166-174.

[41] N.A. Doria-Rose, C.C. Pierce, M.T. Hensel, W.F. Sutton, N. Sheikh, P. Polacino, L. Kuller, Y.D. Zhu, S.L. Hu, D. Anderson, N.L. Haigwood, J. Med. Primatol. 32 (2003) 218-228.

[42] K. Tanabayashi, R. Mukai, A. Yamada, T. Takasaki, I. Kurane, M. Yamaoka, A. Terazawa, E. Konishi, Vaccine 21 (2003) 2338-2345.

[43] U.R. Hengge, P.S. Walker, J.C. Vogel, J. Clin. Invest. 97 (1996) 2911-2916.

[44] N.A. Doria-Rose, C. Ohlen, P. Polacino, C.C. Pierce, M.T. Hensel, L. Kuller, T. Mulvania, D. Anderson, P.D. Greenberg, S.L. Hu, N.L. Haigwood, J. Virol. 77 (2003) 11563-11577.

[45] C.P. Locher, K.F. Sykes, D.J. Blackbourn, S.A. Johnston, J. Med. Primatol. 31 (2002) 323-329.

[46] P. Putkonen, M. Quesada-Rolander, A.C. Leandersson, S. Schwartz, R. Thorstensson, K. Okuda, B. Wahren, J. Hinkula, Virology 250 (1998) 293-301.

[47] S.J. Kent, A. Zhao, S.J. Best, J.D. Chandler, D.B. Boyle, I.A. Ramshaw, J. Virol. 72 (1998) 10180-10188.

[48] D.H. Fuller, P.A. Rajakumar, L.A. Wilson, A.M. Trichel, J.T. Fuller, T. Shipley, M.S. Wu, K. Weis, C.R. Rinaldo, J.R. Haynes, M. Murphey-Corb, J. Virol. 76 (2002) 3309-3317.

[49] D.H. Fuller, P.A. Rajakumar, M.S. Wu, C.W. McMahon, J.T. Fuller, A. Bazmi, A.M. Trichel, T.M. Allen, B. Mothe, J.R. Haynes, D.I. Watkins, M. Murphey-Corb, Virology 348 (2006) 200-215.

[50] R.T. Gandhi, B.D. Walker, Annu. Rev. Med. 53 (2002) 149-172.

[51] P. Piazza, Z. Fan, C.R. Rinaldo Jr., Clin. Lab. Med. 22 (2002) 773-797.

[52] D. Feltquate, S. Heaney, R.G. Webster, H.L. Robinson, J. Immunol. 158 (1997) 2278-2284.

[53] M. Kwissa, K. von Kampen, R. Zurbriggen, R. Gluck, J. Reimann, R. Schirmbeck, Vaccine 18 (2000) 2337-2344.

[54] A.E. Oran, H.L. Robinson, J Immunol. 171 (2003) 1999-2005.

[55] T.M. Pertmer, T.R. Roberts, J.R. Haynes, J. Virol. 70 (1996) 6119 6125.

[56] A. Tanghe, O. Denis, B. Lambrecht, V. Motte, T. van den Berg, K. Huygen, Infect. Immun. 68 (2000) 3854-3860.

[57] E.Y. Enioutina, D. Visic, R.A. Daynes, Vaccine 18 (2000) 2753-2767.

[58] G.M. Glenn, T. Scharton-Kersten, R. Vassell, C.P. Mallett, T.L. Hale, C.R. Alving, J. Immunol. 161 (1998) 3211-3214.
[59] D. Chen, S.B. Periwal, K. Larrivee, C. Zuleger, C.A. Erickson, R.L. Endres, L.G. Payne, J. Virol. 75 (2001) 7956-7965.

[60] R. Putnak, J. Fuller, L. VanderZanden, B.L. Innis, D.W. Vaughn, Am. J. Trop. Med. Hyg. 68 (2003) 469-476.

[61] J. Riemenschneider, A. Garrison, J. Geisbert, P. Jahrling, M. Hevey, D. Negley, A. Schmaljohn, J. Lee, M.K. Hart, L. Vanderzanden, D. Custer, M. Bray, A. Ruff, B. Ivins, A. Bassett, C. Rossi, C. Schmaljohn, Vaccine 21 (2003) 4071-4080.

[62] D.M. Custer, E. Thompson, C.S. Schmaljohn, T.G. Ksiazek, J.W. Hooper, J. Virol. 77 (2003) 9894-9905.

[63] J.W. Hooper, D.M. Custer, J. Smith, V. Wahl-Jensen, Virology 347 (2006) 208-216.

[64] J.T. Fuller, M. Macklin, B. Drape, D. McCabe, W.F. Swain, J.R. Haynes, G. Widera, in: F. Brown, D. Burton, P. Doherty, J. Mekalanos, E. Norrby (Eds.), Vaccines 97: Molecular approaches to the Control of Infectious Diseases, Cold Spring Harbor Laboratory Press, Cold Spring Harbor, NY, 1997, pp. 157-161.

[65] D.L. Lodmell, M.J. Parnell, J.R. Bailey, L.C. Ewalt, C.A. Hanlon, Vaccine 20 (2002) 2221-2228.

[66] M.D. Macklin, D. McCabe, M.W. McGregor, V. Neumann, T. Meyer, R. Callan, V.S. Hinshaw, W.F. Swain, J. Virol. 72 (1998) 1491-1496.

[67] J.W. Hooper, E. Thompson, C. Wilhelmsen, M. Zimmerman, M.A. Ichou, S.E. Steffen, C.S. Schmaljohn, A.L. Schmaljohn, P.B. Jahrling, J. Virol. 78 (2004) 4433-4443.

[68] A.M. Barfoed, B. Kristensen, T. Dannemann-Jensen, B. Viuff, A. Botner, S. Kamstrup, M. Blixenkrone Moller, Vaccine 22 (2004) 13951405.

[69] M.J. Roy, M.S. Wu, L.J. Barr, J.T. Fuller, L.G. Tussey, S. Speller, J. Culp, J.K. Burkholder, W.F. Swain, R.M. Dixon, G. Widera, R. Vessey, A. King, G. Ogg, A. Gallimore, J.R. Haynes, D. Heydenburg Fuller, Vaccine 19 (2000) 764-778.

[70] C.O. Tacket, M.J. Roy, G. Widera, W.F. Swain, S. Broome, R. Edelman, Vaccine 17 (1999) 2826-2829.

[71] R.J. Drape, M.D. Macklin, L.J. Barr, S. Jones, J.R. Haynes, H.J. Dean, Vaccine 24 (2006) 4475-4481.

[72] L.K. Roberts, L.J. Barr, D.H. Fuller, C.W. McMahon, P.T. Leese, S. Jones, Vaccine 23 (2005) 4867-4878.

[73] S.T. Rottinghaus, G.A. Poland, R.M. Jacobson, L.J. Barr, M.J. Roy, Vaccine 21 (2003) 4604-4608.

[74] S.J. McConkey, W.H. Reece, V.S. Moorthy, D. Webster, S. Dunachie, G. Butcher, J.M. Vuola, T.J. Blanchard, P. Gothard, K. Watkins, C.M. Hannan, S. Everaere, K. Brown, K.E. Kester, J. Cummings, J. Williams, D.G. Heppner, A. Pathan, K. Flanagan, N. Arulanantham, M.T. Roberts, M. Roy, G.L. Smith, J. Schneider, T. Peto, R.E. Sinden, S.C. Gilbert, A.V. Hill, Nat. Med. 9 (2003) 729-735.

[75] A.M. Talaat, R. Lyons, S.A. Johnston, Vaccine 20 (2001) 538-544.

[76] T.W. Kim, J.H. Lee, L. He, D.A. Boyd, C.F. Hung, T.C. Wu, Hum. Gene Ther. 16 (2005) 26-34

[77] M. Tachedjian, J.S. Boyle, A.M. Lew, B. Horvatic, J.P. Scheerlinck, J.M. Tennent, M.E. Andrew, Vaccine 21 (2003) 2900-2905.

[78] J. Arrington, R.P. Braun, L. Dong, D.H. Fuller, M.D. Macklin, S.W. Umlauf, S.J. Wagner, M.S. Wu, L.G. Payne, J.R. Haynes, J. Virol. 76 (2002) 4536-4546.

[79] K.F. Sykes, M.G. Lewis, B. Squires, S.A. Johnston, Vaccine 20 (2002) 2382-2395.

[80] H.L. Robinson, D.C. Montefiori, R.P. Johnson, K.H. Manson, M.L. Kalish, J.D. Lifson, T.A. Rizvi, S. Lu, S.L. Hu, G.P. Mazzara, D.L. Panicali, J.G. Herndon, R. Glickman, M.A. Candido, S.L. Lydy, M.S. Wyand, H.M. McClure, Nat. Med. 5 (1999) 526-534.

[81] T. Hanke, R.V. Samuel, T.J. Blanchard, v.C. Neumann, T.M. Allen, J.E. Boyson, S.A. Sharpe, N. Cook, G.L. Smith, D.I. Watkins, M.P. Cranage, A.J. McMichael, J. Virol. 73 (1999) 7524-7532.

[82] T.M. Allen, P. Jing, B. Calore, H. Horton, D.H. O'Connor, T. Hanke, M. Piekarczyk, R. Ruddersdorf, B.R. Mothe, C. Emerson, N. Wilson, J.D. Lifson, I.M. Belyakov, J.A. Berzofsky, C. Wang, D.B. Allison, D.C. Montefiori, R.C. Desrosiers, S. Wolinsky, K.J. Kunstman, J.D. Altman, A. Sette, A.J. McMichael, D.I. Watkins, J. Virol. 76 (2002) 10507-10511. 
[83] T.M. Allen, T.U. Vogel, D.H. Fuller, B.R. Mothe, S. Steffen, J.E. Boyson, T. Shipley, J. Fuller, T. Hanke, A. Sette, J.D. Altman, B. Moss, A.J. McMichael, D.I. Watkins, J. Immunol. 164 (2000) 4968-4978.

[84] H. Horton, T.U. Vogel, D.K. Carter, K. Vielhuber, D.H. Fuller, T. Shipley, J.T. Fuller, K.J. Kunstman, G. Sutter, D.C. Montefiori, V Erfle, R.C. Desrosiers, N. Wilson, L.J. Picker, S.M. Wolinsky, C. Wang, D.B. Allison, D.I. Watkins, J. Virol. 76 (2002) 7187-7202.

[85] T.U. Vogel, M.R. Reynolds, D.H. Fuller, K. Vielhuber, T. Shipley, J.T. Fuller, K.J. Kunstman, G. Sutter, M.L. Marthas, V. Erfle, S.M. Wolin- sky, C. Wang, D.B. Allison, E.W. Rud, N. Wilson, D. Montefiori, J.D. Altman, D.I. Watkins, J. Virol. 77 (2003) 13348-13360.

[86] J.W. Hooper, D.M. Custer, E. Thompson, Virology 306 (2003) 181-195.

[87] A.M. Barfoed, M. Blixenkrone-Moller, M.H. Jensen, A. Botner, S. Kamstrup, Vaccine 22 (2004) 3628-3641.

[88] G. Rompato, E. Ling, Z. Chen, H. Van Kruiningen, A.E. Garmendia, Vet. Immunol. Immunopathol. 109 (2006) 151-160.

[89] C. Beard, G. Ward, E. Rieder, J. Chinsangaram, M.J. Grubman, P.W. Mason, J. Biotechnol. 73 (1999) 243-249. 